or bottle feeding. Before discharge mother stays for a couple of nights and has complete charge of the baby in her room but with the support of staff close by.

Such participation and the continuing practical care parents are encouraged to give are critical. Going home follows naturally, irrespective of age or weight. Good liaison between hospital and community services, especially the home health visitor, is essential, and ideally the family doctor and health visitor will visit the family at home before discharge. In Leicester the general-practice health visitor supervises care at home. Our door is always open, however, and parents are encouraged to phone or visit at any time. The follow-up clinic is integral to support, and parents see people whom they know. Readmissions soon after discharge are almost invariably to the neonatal unit, care being given by staff who had looked after the baby before.

Possible complications of early discharge-feeding problems, maternal anxiety, increased community work load-have not occurred, and some 5000 nursing hours a year have been saved.

Prolonged separation of preterm babies from their parents might be harmful for psychological wellbeing ${ }^{4}$ and contribute to risks of nonaccidental injury, to which such infants are vulnerable. ${ }^{5} \mathrm{~A}$ more critical appraisal of discharge policies might help to minimise these hazards.

We thank the many nurses and doctors of the neonatal unit whose constant support and encouragement of parents makes it possible for small babies to be reunited at home with their families at the earliest possible time. We also thank Miss S Mangal for help with typing the manuscript.

${ }^{1}$ Davies DP, Haxby V, Herbert S, McNeish AS. When should preterm babies be sent home from neonatal units? Lancet $1979 ; \mathrm{i}: 914-5$.

2 Berg RB, Salisbury AJ. Discharging infants of low birth weight. Am $\mathcal{F}$ Dis Child 1973;122:414-7.

${ }^{3}$ Singer B, Wolfsdorf J. Early discharge of infants of low birth weight: a prospective study. $\mathrm{Br}$ Med $\mathcal{F} 1975 ; \mathrm{i}: 362-4$.

4 Anonymous. Separation and special care baby units. Lancet $1979 ; \mathrm{i}: 590-1$

${ }^{5}$ Murphy JF, Jenkins J, Newcombe RG, Sibert JM. Objective birth data and the prediction of child abuse. Arch Dis Child 1981 ;56:295-7.

(Accepted 22 September 1981)

Neonatal Unit, Leicester Royal Infirmary Maternity Hospital, Leicester LE1 5WW

F DERBYSHIRE, SRN, RSCN, nursing officer

D P DAVIES, MD, FRCP, senior lecturer in child health and honorary consultant

A BACCO, ward assistant

\section{Medical nephrectomy with anti-inflammatory non-steroidal drugs}

A nephrotic syndrome may persist despite end-stage renal disease. Such a condition, due to massive proteinuria and subsequent hypovolaemia, leads to major problems in the management of patients and can be life-threatening. Treatment to stop the proteinuria is, in some cases, mandatory. Recent data have underlined the deleterious effect of anti-inflammatory non-steroidal drugs on renal function in various conditions, including the nephrotic syndrome. ${ }^{1}$ As indicated by this case the use of anti-inflammatory non-steroidal drugs may be a safe and easy way of inducing medical nephrectomy in patients with severe nephrotic syndrome which persists despite terminal renal failure.

\section{Case report}

A 44-year-old man with no history of renal disease was referred in September 1978 for treatment of membranous nephropathy with nephrotic syndrome. Over the next 18 months he developed progressive renal failure, muscle wasting, and refractory oedema.

In April 1980 examination showed massive oedema, ascites, pleural effusion, and blood pressure of $100 / 70 \mathrm{~mm} \mathrm{Hg}$ with orthostatic hypotension. Serum creatinine concentration was $726 \mu \mathrm{mol} / 1(8.2 \mathrm{mg} / 100 \mathrm{ml})$ and creatinine clearance $0.15 \mathrm{~m} / \mathrm{ls}$; urine contained $31 \mathrm{~g}$ of protein $/ 24 \mathrm{~h}$; serum proteins were $35 \mathrm{~g} / 1$ and serum albumin $15 \mathrm{~g} / \mathrm{l}$. The oedema persisted despite severe sodium restriction and high doses of frusemide $(500 \mathrm{mg} /$ day $)$ and spironolactone (100 mg/day).

Suppression of renal function, with the prospect of future peritoneal dialysis, was taken into consideration and various techniques discussed. On the basis of our experience, ${ }^{2}$ we suggested medical nephrectomy using indomethacin to the patient, and treatment was started. The effect of indomethacin on diuresis was immediate, despite the continued administration of frusemide. The patient became oliguric on the first day and anuric on the fourth day.

Continuous peritoneal dialysis, using a semi-automatic cycling machine, was performed during the first two days, followed by continuous ambulatory peritoneal dialysis. Despite a protein loss of 3 to $10 \mathrm{~g} /$ day in the drainage fluid, total serum proteins and albumin rose sharply (see figure), and normal values were reached within two weeks.

Indomethacin $150 \mathrm{mg} /$ day was continued for two weeks. The dosage was then decreased progressively and finally stopped after two months. One year later the patient remained well and had returned to work. He was still anuric, having regular haemodialysis.

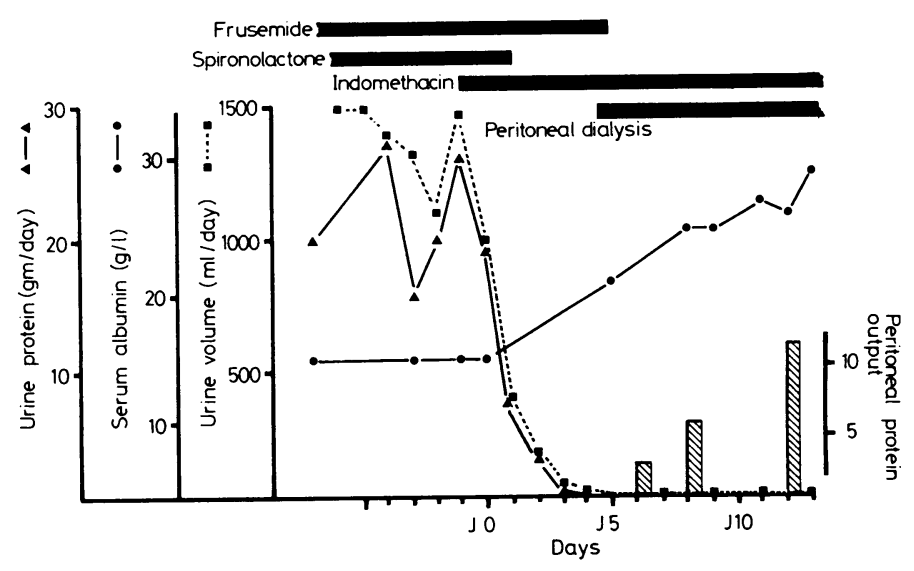

Severe nephrotic syndrome: course before and during indomethacin administration.

\section{Comment}

This is, to our knowledge, the first report of a medical nephrectomy voluntarily induced by anti-inflammatory non-steroidal drugs. Indomethacin was selected because it was considered one of the more potent inhibitors of the prostaglandin synthetase, and the increase in renal prostaglandin synthesis is a major factor in maintaining adequate blood flow when glomerular filtration is reduced. ${ }^{3}$ An acute inhibition of such synthesis by anti-inflammatory non-steroidal drugs could trigger the onset of renal insufficiency. This effect is usually reversible, however, and most clinical observations indicate that the initial renal function recovers when the drug is stopped and conservative medical management started. In our case the desired prolonged anuria may have been the consequence of previous chronic anatomical renal lesions, the severity of the nephrotic syndrome, and the prolonged administration of indomethacin.

The induced anuria was easily treated with peritoneal dialysis. Despite an average daily peritoneal protein loss of $7 \mathrm{~g}$, total serum protein and albumin increased rapidly, and later the serum protein values remained normal. The discrepancy between the effects of high protein losses in relation to their renal or peritoneal origins may be explained by the fact that in the nephrotic syndrome, the amount of protein catabolised by the tubule is several times higher than the amount of protein recovered in the urine. ${ }^{4}$

Further clinical trials are needed to define an adequate monitoring of the indomethacin required to induce a permanent or even a temporary medical nephrectomy and to specify the best indications of this protocol.

${ }^{1}$ Dunn MJ, Zambraski EJ. Renal effects of drugs that inhibit prostaglandin synthesis. Kidney Int 1980;18:609-22.

2 Baumelou A, Agrafiotis A, Jacobs C. Insuffisance rénale aiguë au cours des traitements par l'indometacine. Nouv Presse Med 1980;47:3611-4.

${ }^{3}$ Epstein M, Lifschitz MD. Volume status as a determinant of the influence of renal PGE on renal function. Nephron $1980 ; 25: 157-9$.

4 Bourdeau JE, Carone FA. Protein handling by the renal tubule. Nephron $1974 ; 13: 22-34$.

(Accepted 7 October 1981)

Department of Nephrology, Groupe Hospitalier Pitié-Salpétrièr, 75634 Paris, France

ALAIN BAUMELOU, MD, assistant

MARCEL LEGRAIN, MD, professor of nephrology

(n)

